\title{
MicroRNA Exocytosis by Vesicle Fusion in Neuroendocrine Cells
}

\author{
Yongsoo Park* \\ Department of Molecular Biology and Genetics, Koç University, Istanbul, Turkey
}

MicroRNAs (miRNAs) are short non-coding RNAs that posttranscriptionally regulate gene expression inside the cell. Extracellular circulating miRNAs are also observed outside the cell, but their origin is poorly understood. Recently, miRNA has been shown to be exocytosed by vesicle fusion; this observation demonstrates that vesicle-free miRNAs are secreted from neuroendocrine cells, in a manner similar to hormone secretion. miRNAs are stored in large dense-core vesicles together with catecholamines, then released by vesicle fusion in response to stimulation; in this way, vesicle-free miRNA may regulate cell-to-cell communication including the regulation of gene expression and cellular signaling. Therefore, miRNA has been suggested to function as a hormone; i.e., a ribomone (ribonucleotide + hormone). This review focuses on the mechanisms by which vesicle-free miRNAs are secreted from neuroendocrine cells and will discuss potential functions of vesicle-free miRNAs and how vesicle-free miRNAs regulate cell-to-cell communication.

OPEN ACCESS

Edited by:

Chun Peng,

York University, Canada

Reviewed by:

Maria-Dolors Piulachs,

Consejo Superior de Investigaciones

Cientificas (CSIC), Spain

Wilson C. J. Chung,

Kent State University, United States

*Correspondence:

Yongsoo Park

ypark@ku.edu.tr

Specialty section:

This article was submitted to Experimental Endocrinology,

a section of the journal

Frontiers in Endocrinology

Received: 27 September 2017 Accepted: 07 December 2017 Published: 22 December 2017

Citation:

Park Y (2017) MicroRNA Exocytosis by Vesicle Fusion in Neuroendocrine Cells.

Front. Endocrinol. 8:355. doi: 10.3389/fendo.2017.00355

\section{Keywords: microRNA, fusion, chromaffin cells, large dense-core vesicles, neuroendocrine cells, SNARE}

\section{INTRODUCTION}

MicroRNAs (miRNAs) are a class of small non-coding RNAs (ncRNAs) that are 22 nucleotides in length; they downregulate translation of target mRNA $(1,2)$. ncRNAs are transcribed from the genome, but not translated to protein; $98 \%$ of RNA transcripts in humans are non-coding (3). Although miRNAs constitute $<1 \%$ of ncRNAs in mammalian cells (4); tRNA and rRNA are dominant ncRNAs, miRNAs have critical functions in gene expression.

MicroRNAs inhibit expression of $>60 \%$ of human protein-coding genes, mostly by binding to the $3^{\prime}$ - untranslated region ( $3^{\prime}$ UTR) of the target mRNAs (5) and, therefore, miRNAs affect gene expression networks of a variety of biological processes including development, apoptosis, proliferation, and metabolism $(1,2)$. miRNAs are transcribed within cells, but are also found outside cells, called extracellular miRNAs. Extracellular miRNAs were observed in cell culture system (6), in blood plasma and serum (7-10), and in other biological fluids (11) including cerebrospinal fluid (12), saliva (13), breast milk, urine, and tears (14). The existence of extracellular miRNAs suggests that they participate in cell-to-cell communication. Extracellular miRNAs are highly stable in freeze-thaw cycles, extreme $\mathrm{pH}$, and can withstand storage for up to 4 days at room temperature $(9,10,15)$.

Extracellular miRNAs can be non-invasive biomarkers for many different types of diseases (16-19), although the specificity and sensitivity of miRNA biomarkers are still under debate (20), for three reasons: (1) tumor-derived extracellular miRNAs can also be released by normal cells; (2) existing protocols for collecting extracellular miRNAs are not sufficiently reproducible; and (3) the level of tumor-derived extracellular miRNAs might vary with the age of the patient and the status of disease, so their value as non-invasive biomarkers are reduced.

Exosomes, microvesicles, and apoptotic bodies are considered as carriers of extracellular miRNAs (21). More than $90 \%$ of extracellular miRNAs are vesicle-free, but form a complex with proteins such 
as Agonaute2 (AGO2) (22, 23). Although extracellular miRNAs are believed to contribute to cell-to-cell communication, the mechanisms by which miRNAs are released are still not understood. Extracellular miRNAs have been considered as byproducts or artifacts caused by cell lysis and cell death. Recently, miRNA exocytosis by vesicle fusion in response to stimulation was observed in chromaffin cells, which are neuroendocrine cells in the sympathetic nervous system (24). The objective of this review is to discuss how miRNAs are released by active exocytosis and to examine the physiological functions of vesicle-free miRNAs in neuroendocrine cells.

\section{CARRIER OF EXTRACELLULAR miRNAs}

The biogenesis of miRNAs has been extensively reviewed elsewhere (25-27). RNA polymerase II mainly transcribes microRNA genes as primary miRNA transcripts (pri-miRNAs) that contain 5'cap and 3'poly(A) tails (28). Drosha, RNase III, and DGCR8, the RNA-binding protein, further process pri-miRNAs into stemloop structured precursor miRNAs (pre-miRNAs) of $70 \mathrm{nt}$ (29). After pre-miRNAs are transported to the cytoplasm, RNase III Dicer and TRBP (transactivation-response RNA-binding protein) cleave them into double-stranded miRNA duplexes of $\sim 22 \mathrm{nt}$ $(30,31)$. Finally, argonaute (AGO) proteins associate with mature miRNAs in the RNA-induced silencing complex (RISC) (32-34) and mature miRNAs bind to the complementary sequence usually located within the $3^{\prime}$-UTR of target mRNAs (35). AGO protein family (AGO1, AGO2, AGO3, AGO4) associating with miRNA mediate mRNA decay and inhibition of mRNA translation, whereas only AGO2 cleaves target mRNAs $(32,36)$.

Exosomes, microvesicles, and apoptotic bodies deliver extracellular miRNAs to target cells (21). Exosome-incorporated extracellular miRNAs were first observed in 2007 (6). Exosomes contain miRNAs and mediate the transfer of miRNAs between cells (6). Release of exosomal miRNA is dependent on ceramide, which is regulated by neutral sphingomyelinase 2 (nSMase2), but independent of the endosomal sorting complex required for transport (ESCRT) $(37,38)$. Rab27a and Rab27b control exosome secretion by regulating docking of multivesicular bodies (MVBs) at the plasma membrane (39).

Exosomes are small vesicles (40-100 $\mathrm{nm}$ in diameter) and are thought to be the carriers of signaling macromolecules and RNAs for cell-to-cell communication, but the true function of exosomes remain poorly understood (40-42). MVBs store exosomes and release exosomes by fusion with the plasma membrane (43). However, the number of copies of miRNAs per exosome is very low; i.e., <1 (44), and exosomes can be very heterogeneous in molecular composition depending on the purification methods (45). Furthermore, further research is required to determine the mechanism by which exosomal miRNAs $(44,46,47)$ affect gene silencing in the target cell, despite their low concentrations [see Table 1 for comparison with large dense-core vesicles (LDCVs)].

Microvesicles from the plasma contain miRNAs and transfer extracellular miRNAs (57). Microvesicles are generated by outward budding of the plasma membrane and are larger $(50-2,000 \mathrm{~nm})$ than exosomes (58). The sizes of some microvesicles and exosomes are similar and the molecular compositions of microvesicles and exosomes largely overlap (59), so, the classes are difficult to distinguish; thus, they can be collectively called extracellular vesicles (EVs).

Apoptotic bodies with diameters 1-4 $\mu$ m contain extracellular miRNAs (60), but apoptotic bodies form only after programmed cell death, and miRNAs in apoptotic bodies seem to be byproducts released by cell lysis. Researchers still debate whether extracellular miRNAs are the specific cargo of EVs and apoptotic bodies, or whether miRNAs are just byproducts of the biogenesis of EVs and apoptotic bodies.

\section{EXTRACELLULAR VESICLE-FREE miRNAs}

Extracellular miRNAs fall into vesicle-incorporated and vesiclefree groups. More surprisingly, 90-99\% of extracellular miRNAs are vesicle-free, and are components of miRNA-protein complexes; this result suggests that exosomes are not the main miRNA carriers $(22,23)$. Extracellular vesicle-free miRNAs being exported by the protein complexes that protect miRNAs from degradation, e.g., nucleophosmin 1 (NPM1), in the cell culture system were first reported in 2010 (61). miR-16 and miR-92a are not contained in EVs, but associate with AGO2 that protect extracellular miRNAs from RNases (22). miR-16, miR-21, and miR-24 are EV-free extracellular miRNAs that form complexes with AGO2 (23). In addition to AGO2, apolipoprotein A-I (apoA-I), the main component of high-density lipoprotein (HDL), associates with extracellular miRNAs in plasma and transfers miRNAs to target cells; the transfer is mediated by a scavenger receptor class $\mathrm{B}$, type I (SR-BI) HDL receptor in the plasma membrane $(62,63)$, and thereby contributes to intercellular communication.

TABLE 1 | Comparison of large dense-core vesicle (LDCV) and exosomea.

\begin{tabular}{|c|c|c|}
\hline & LDCV & Exosome $^{a}$ \\
\hline Size (diameter) & $100-300 \mathrm{~nm}$ & $40-100 \mathrm{~nm}$ \\
\hline Biogenesis/formation & Golgi complex & Multivesicular bodies, endosome \\
\hline Agonaute2 and RNA-induced silencing complex & No (24) & Yes (48) \\
\hline Copy number of miRNA & 500 (miR-375) (24) & $<1$ \\
\hline Size distribution of RNA & Peak at $\sim 22 \mathrm{nt}(24)$ & Broad distribution, 25-4,000 nt (49) \\
\hline Dominant RNA & $\sim 60 \%$ miRNA (24) & mRNA, miRNA is minor $(<1-30 \%(49-52))$ \\
\hline Contents & Catecholamines, hormones, peptide, ATP, miRNA & Proteins, DNA, RNA, lipid (42, 53-55) \\
\hline miRNA release mechanism & Neuronal SNARE (VAMP-2, syntaxin-1A, SNAP-25A) (56) & Ceramide-dependent, ESCRT-independent $(37,38)$ \\
\hline
\end{tabular}

aExosome composition is so heterogeneous that the RNA profile and content of exosomes varies depending on cell types, references; i.e., serum, plasma, or cell culture medium, developmental stages, etc. 
Despite the interests of extracellular vesicle-free miRNAs, the origin of vesicle-free miRNAs and the mechanisms of their release are unclear. Vesicle-free miRNAs might be byproducts of cell death (23); death of neurons and glial cells in neurodegenerative diseases lead to an increase in extracellular vesicle-free miRNAs, and this increase can be exploited as a biomarker (64). In contrast, certain vesicle-free miRNA species are selectively released from various types of cells (61); this result suggests the existence of a specific pathway that is independent of EVs for release of miRNAs. However, the mechanisms by which vesiclefree miRNA is released remain unknown.

\section{MIRNA EXOCYTOSIS BY VESICLE FUSION}

Neuroendocrine cells can release vesicle-free miRNAs by active exocytosis in response to neuronal stimuli (24). Chromaffin cells are neuroendocrine cells that release hormones and catecholamines (e.g., dopamine, adrenaline, noradrenaline) into the blood when the sympathetic nervous system is activated (65). LDCVs of chromaffin cells are specialized organelles that store catecholamines and hormones (65). miRNAs are stored in LDCVs of chromaffin cells together with catecholamines and hormones (see Table 1 for comparison with exosome); miR-375 is the most abundant miRNA ( $\sim 30 \%$ of total miRNAs in LDCV) (24). miRNAs including miR-375 are released by LDCV fusion in a manner that is dependent on the presence of soluble $N$-ethylmaleimidesensitive factor attachment protein receptor (SNARE). SNARE proteins are considered to constitute the fusion machinery that draws two opposing membranes close together (66). Neuronal SNAREs including VAMP-2, SNAP-25A, and syntaxin-1A mediate miRNA exocytosis in neuroendocrine cells (Figure 1A) (24), whereas VAMP-3 and SNAP-23 mediate secretion of vesicle-free miRNA in vascular endothelial cells (67). miRNA exocytosis is completely inhibited when neuronal SNAREs are absent in the in vitro reconstitution system, suggesting that neuronal SNAREs mediate the release of miRNAs in chromaffin cells (24).

$\mathrm{Ca}^{2+}$ is a triggering factor of vesicle fusion and synaptotagmin-1 (Syt-1) is a $\mathrm{Ca}^{2+}$ sensor for fast exocytosis in neurons (68) and neuroendocrine cells including chromaffin cells (56). The membrane insertion of Syt- 1 into the plasma membrane triggers $\mathrm{Ca}^{2+}$-dependent vesicle fusion (69). miR-375 exocytosis is accelerated by the $\mathrm{Ca}^{2+}$ influx that provokes LDCV fusion in PC-12 cells, the cell line of chromaffin cells as well as the in vitro reconstitution system (24); this observation is evidence that miRNA exocytosis is coupled to neuronal stimuli, and that Syt- 1 is a $\mathrm{Ca}^{2+}$ sensor for miRNA exocytosis in neuroendocrine cells (Figure 1A).

Large dense-core vesicles are enriched with miRNAs that account for $\sim 60 \%$ of total RNAs stored in LDCVs; the copy number of miR-375 stored in a single LDCV is $~ 500(24)$, which is extremely high compared to the copy number $(<1)$ in

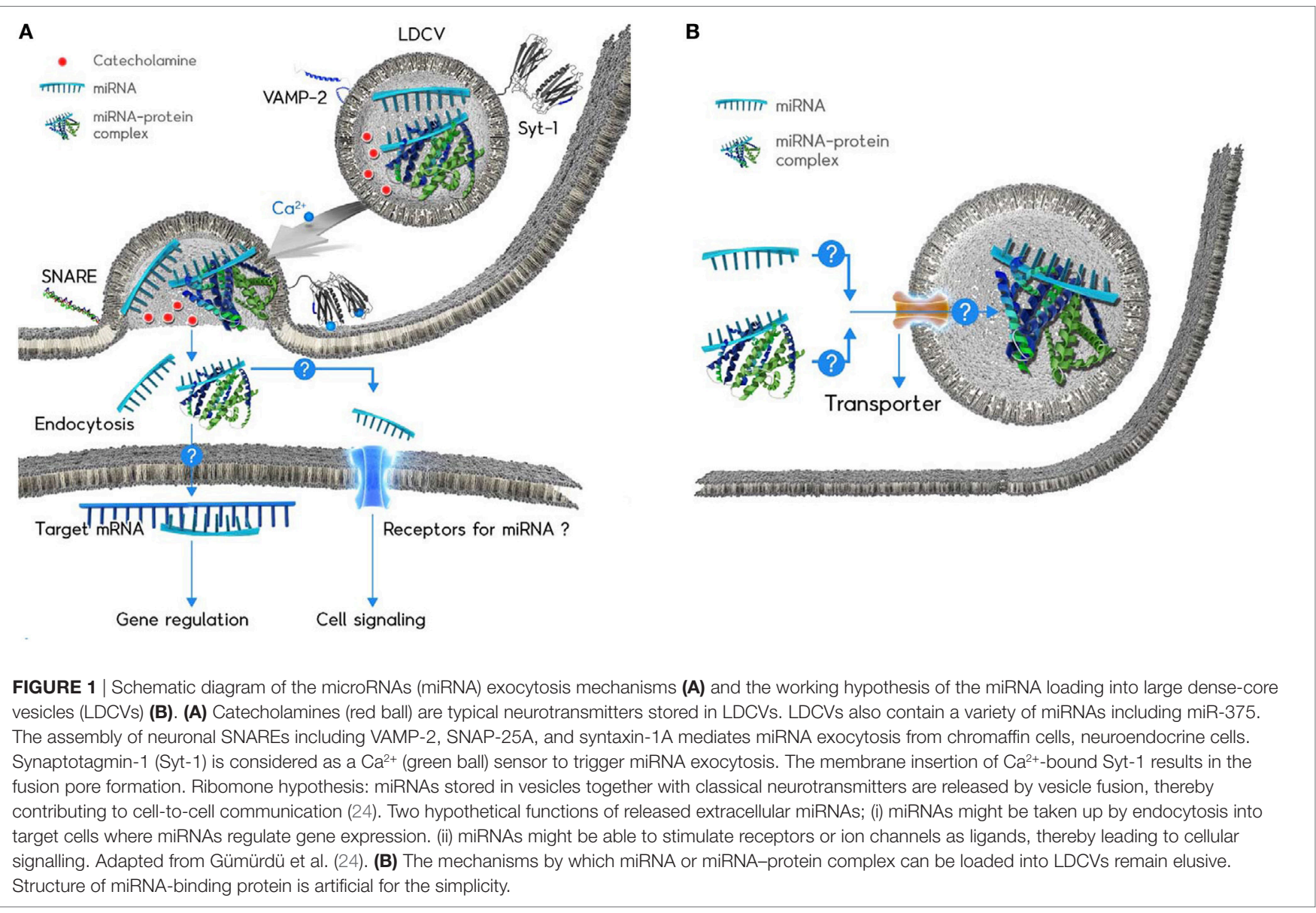


exosomes $(44,46)$ (see Table 1). miR-375 is preferentially stored in LDCVs in chromaffin cells, but not in synaptic vesicles in neurons (24); this segregation suggests that miRNA exocytosis by LDCV fusion is specific. Thus, a new term: ribomone (ribonucleotide + hormone) has been proposed; i.e., miRNA can function as a hormone, which is stored in vesicles and released by vesicle fusion together with neurotransmitters in response to stimulation, and in this way, contributes to cell-to-cell communication (24).

Vesicle-free miRNAs are highly stable. One possibility is they are stabilized by RNA-binding proteins outside the cells, e.g., by AGO2 (22, 23), apoA-I (62), and NPM1 (61). The mechanism of this stabilization in LDCVs after exocytosis remains unknown, but two hypotheses can be proposed. LDCVs contain apoA-I, but neither AGO2 nor NPM1 (24), thereby, it remains to be tested that apoA-I binds and stabilizes miRNAs. Another possibility is that secreted miRNAs bind to AGO2 that exists outside the cells and AGO2 might stabilize secreted miRNAs. We also cannot exclude the possibility that other RNA-binding proteins might be involved in miRNA stability.

miR-375 is specifically expressed in endocrine and neuroendocrine cells, including pancreatic islets beta-cells, pituitary gland, and adrenal medulla chromaffin cells (70, 71); miR-375 is specifically located in the intermediate lobe of pituitary (72). Organs and cells expressing miR-375 are linked in hormone secretion. miR-375 inhibits catecholamine biogenesis by reducing the expression of tyrosine hydroxylase and dopamine-betahydroxylase in chromaffin cells (73). miR-375 is one of the first miRNAs that was identified in the pancreas; miR-375 regulates development of pancreatic islets (74) and normal pancreatic cell mass (71). miR-375 also reduces insulin secretion by suppressing expression of myotrophin (70) and phosphoinositide-dependent protein kinase-1 (PDK1) (75). In the pituitary gland, miR-375 targets mitogen-activated protein kinase 8 , and as a result, inhibits expression of pro-opiomelanocortin and secretion of pituitary hormones (72). Whether miR-375 is also released by active exocytosis from beta cells and the pituitary gland remains to be determined.

miR-375 is one of the circulating miRNAs in plasma and serum, and might be a biomarker for diabetes (76), hepatocellular carcinoma (77), and Alzheimer's disease (78). However, it is still under debate as a biomarker, since circulating miRNAs are not diseasespecific. Because catecholamines released by LDCV fusion spread through the blood, LDCVs in chromaffin cells can be one source of circulating miR-375, but the function of miR-375 remains to be elucidated in both normal and pathological conditions.

Large dense-core vesicles in neurons might also contain miRNAs. miR-29a and miR-125a are released from synaptosomes in response to depolarization (79), and both miR-29a and miR$125 \mathrm{a}$ are among the top $10 \%$ most-abundant miRNAs in LDCVs (24). let-7b is also released from dorsal root ganglion neurons by depolarization; let-7b stimulates the toll-like receptor-7 (TLR7)/TRPA1 ion channel to mediate pain signaling (80). let$7 \mathrm{~b}$ is among the $15 \%$ most-abundant miRNAs in LDCVs (24). However, whether these miRNAs are released by LDCV or by synaptic vesicle fusion in neurons remains unknown, as does the physiological function of secreted miRNAs.

\section{PHYSIOLOGICAL FUNCTIONS OF EXTRACELLULAR mIRNAs}

Even though miRNA exocytosis is selective in response to stimulus in neuroendocrine cells (24), the hypothesis that vesiclefree miRNAs act as signaling molecules and mediate cell-to-cell communication is still challenging. The biological roles of vesiclefree miRNAs remain elusive. Two possibilities are proposed: (1) gene silencing in target cells after endocytosis and (2) cellular signaling by receptor activation.

\section{miRNA Transport to Regulate Gene Expression in Target Cells}

The miRNA transport system between different cells for cellto-cell communication has been intensively reported including exosomes (81-83), but this review focuses on functional transfer of vesicle-free miRNA. The first evidence of miRNA transport between cells came from plants. Plasmodesmata are channels that traverse the cell walls of plant cells; miRNA are transported directly through plasmodesmata, thus inducing systemic gene silencing of mRNAs in target cells $(84,85)$.

In the nematode Caenorhabditis elegans, SID-1 (a transmembrane channel for dsRNA) and SID-2 (dsRNA transporter) have important functions in uptake of extracellular vesicle-free miRNA into the cytosol; miRNA can be internalized by SID-2-mediated endocytosis and then transported into the cytosol through the SID-1 channel $(86,87)$. The human SID-1 ortholog SIDT1 facilitates miRNA transfer between human cells (88). In addition to channels of small RNA, miRNA might be transported into the cytosol through HDL receptor SRBI. The complex of HDL with extracellular vesicle-free miRNAs in human plasma binds to SRBI and miRNA delivery might be mediated by a cell surface HDL receptor SRBI (62); however, SRBI-mediated miRNA transfer is still not significant and remains controversial (89). AGO2 and/or NPM1 bind to extracellular vesicle-free miRNAs in cell culture and the protein-miRNA complex might facilitate miRNA uptake into target cells $(61,79)$. Additionally, secreted miRNAs might be taken up into neurons by endocytosis (79) or through gap junctions in the direct cell contact $(90,91)$ to regulate the translation of targeted mRNAs. However, little is known about the mechanisms by which extracellular vesicle-free miRNAs can be transported and regulate gene expression in target cells.

\section{Cellular Signaling via Receptor Activation}

An unconventional function of miRNA as an agonist of toll-like receptor (TLR) was discovered in 2012: vesicle-free miRNAs interact with TLR7 and TLR8 and, in this way, activate the downstream signaling pathway $(92,93)$. Tumor-secreted miR-21 and miR-29a stimulate murine TLR7 and human TLR8 in immune cells, and thereby trigger a TLR-mediated inflammatory response (92). Extracellular let-7 activates the TLR7 and induces neurodegeneration through neuronal TLR7 (93). let-7b induces inflammatory pain by activating TLR7 in a sequence-dependent manner as an agonist in dorsal root ganglia (80).

MicroRNAs might evoke cellular signaling by stimulating receptors in the plasma membrane, but the tissue origins of 
extracellular miRNAs remain unknown. LDCVs in chromaffin cells is one of the origins of extracellular vesicle-free miRNAs, because miR-21, miR-29a, and let-7b are among the 5, 10, and $15 \%$ most-abundant miRNAs in LDCVs, respectively (24); this abundance suggests that miRNA may serve as a receptor agonist. However, the binding site of miRNA and receptors is not known at the molecular level. Furthermore, the RNA-binding proteins that can regulate miRNA function to stimulate receptors remain unknown, because free miRNA without protein partners would be highly unstable. Crosslinking protocols can be applied to investigate miRNA-binding proteins that stabilize miRNA after exocytosis.

\section{POSSIBLE MECHANISMS OF MIRNA LOADING INTO LDCVs}

Several groups have provided evidence for miRNA sorting into exosomes. Direct contact of miRNAs with MVB membranes might be important for miRNA sorting (94) and universal sequence-specific sorting mechanisms for miRNA loading into EVs have been proposed (95). hnRNPA2B1 protein that recognizes the specific GGAG motif within miRNAs may mediate miRNA sorting into exosomes (96). However, the mechanisms of miRNA sorting into EVs remain largely unclear.

Selective packing of miRNAs to LDCVs is also unknown. Given that miR-375 constitutes $~ 30 \%$ miRNAs stored in LDCVs (24), LDCVs probably uptake miRNAs selectively. Two possible pathways should be considered: (1) because LDCVs in neuroendocrine cells bud off the Golgi complex and undergo maturation (97), miRNAs might be incorporated into LDCVs during biogenesis and (2) RNA transporters in vesicle membranes might uptake miRNA into LDCVs (Figure 1B). However, this hypothesis still requires investigation of how miRNAs are packaged into LDCVs in endocrine and neuroendocrine cells.

\section{CONCLUSION}

Large dense-core vesicles in chromaffin cells contain miRNAs, which are released in response to stimulation, together with catecholamines and peptides. miRNA exocytosis by the SNARE complex and Syt-1 has been discovered in chromaffin cells and additional secreted vesicle-free miRNAs are expected to be

\section{REFERENCES}

1. Ambros V. The functions of animal microRNAs. Nature (2004) 431:350-5. doi:10.1038/nature02871

2. Bartel DP. MicroRNAs: genomics, biogenesis, mechanism, and function. Cell (2004) 116:281-97. doi:10.1016/S0092-8674(04)00045-5

3. Frith MC, Pheasant M, Mattick JS. The amazing complexity of the human transcriptome. Eur J Hum Genet (2005) 13:894-7. doi:10.1038/sj.ejhg. 5201459

4. Palazzo AF, Lee ES. Non-coding RNA: what is functional and what is junk? Front Genet (2015) 6:2. doi:10.3389/fgene.2015.00002

5. Friedman RC, Farh KK, Burge CB, Bartel DP. Most mammalian mRNAs are conserved targets of microRNAs. Genome Res (2009) 19:92-105. doi:10.1101/ gr.082701.108 discovered. miRNAs have hormone-like activities; i.e., they are secreted from neuroendocrine cells, spread through the blood stream, and regulate target cells by gene expression and/or cellular signaling. This activity of secreted miRNAs is opening an exciting research area in RNA biology, endocrinology, and neuroscience, but several important questions remain unanswered, including: (1) what are the physiological functions of secreted and vesicle-free miRNAs? It becomes clear that miRNA are secreted by vesicle fusion, but there is little evidence showing the functions of these secreted miRNAs. Further studies should focus on (i) the mechanism of miRNA endocytosis to mediate gene regulation in a target cell and (ii) miRNA receptors that might be activated by secreted miRNAs (Figure 1A). (2) Which cells can release vesicle-free miRNA? In addition to chromaffin cells, other neuroendocrine cells need to be tested whether miRNA is able to be released by vesicle fusion in a SNARE-dependent manner. (3) How can miRNA be stabilized after exocytosis? miRNAs stored in LDCVs are highly stable after exocytosis, but the mechanisms of miRNA stability and which proteins stabilize miRNAs remain to be elucidated. (4) How can miRNA be loaded into LDCVs? $\sim 500$ copies of miR-375 are accumulated inside a LDCV, but the loading mechanism of miR-375 remains mysterious. Further studies are required to determine whether there is a miRNA transporter that uploads miRNAs (Figure 1B).

Extracellular vesicle-free miRNAs are considered to contribute to cell-to-cell communication, but the physiological action and the target of extracellular miRNAs remain to be elucidated. In-depth knowledge of extracellular vesicle-free miRNAs will lead to the new research field that miRNAs may behave as hormones to regulate cell-to-cell communication in a paracrine and endocrine manner.

\section{AUTHOR CONTRIBUTIONS}

YP designed and wrote the manuscript.

\section{ACKNOWLEDGMENTS}

The author is grateful to Dr. Bruno Quérat and Joëlle CohenTannoudji for helpful discussions and comments. This work was supported by EMBO Installation Grant (IG Project Number 3265 to YP).
6. Valadi H, Ekström K, Bossios A, Sjöstrand M, Lee JJ, Lötvall JO. Exosomemediated transfer of mRNAs and microRNAs is a novel mechanism of genetic exchange between cells. Nat Cell Biol (2007) 9:654-9. doi:10.1038/ncb1596

7. Chim SS, Shing TK, Hung EC, Leung TY, Lau TK, Chiu RW, et al. Detection and characterization of placental microRNAs in maternal plasma. Clin Chem (2008) 54:482-90. doi:10.1373/clinchem.2007.097972

8. Lawrie CH, Gal S, Dunlop HM, Pushkaran B, Liggins AP, Pulford K, et al. Detection of elevated levels of tumour-associated microRNAs in serum of patients with diffuse large B-cell lymphoma. Br J Haematol (2008) 141:672-5. doi:10.1111/j.1365-2141.2008.07077.x

9. Mitchell PS, Parkin RK, Kroh EM, Fritz BR, Wyman SK, PogosovaAgadjanyan EL, et al. Circulating microRNAs as stable blood-based markers for cancer detection. Proc Natl Acad Sci U S A (2008) 105:10513-8. doi:10.1073/pnas.0804549105 
10. Chen X, Ba Y, Ma L, Cai X, Yin Y, Wang K, et al. Characterization of microRNAs in serum: a novel class of biomarkers for diagnosis of cancer and other diseases. Cell Res (2008) 18:997-1006. doi:10.1038/cr.2008.282

11. Turchinovich A, Weiz L, Burwinkel B. Extracellular miRNAs: the mystery of their origin and function. Trends Biochem Sci (2012) 37:460-5. doi:10.1016/j. tibs.2012.08.003

12. Cogswell JP, Ward J, Taylor IA, Waters M, Shi Y, Cannon B, et al. Identification of miRNA changes in Alzheimer's disease brain and CSF yields putative biomarkers and insights into disease pathways. J Alzheimers Dis (2008) 14:27-41. doi:10.3233/JAD-2008-14103

13. Park NJ, Zhou H, Elashoff D, Henson BS, Kastratovic DA, Abemayor E, et al. Salivary microRNA: discovery, characterization, and clinical utility for oral cancer detection. Clin Cancer Res (2009) 15:5473-7. doi:10.1158/1078-0432. CCR-09-0736

14. Weber JA, Baxter DH, Zhang S, Huang DY, Huang KH, Lee MJ, et al. The microRNA spectrum in 12 body fluids. Clin Chem (2010) 56:1733-41. doi:10.1373/clinchem.2010.147405

15. Glinge C, Clauss S, Boddum K, Jabbari R, Jabbari J, Risgaard B, et al. Stability of circulating blood-based microRNAs - pre-analytic methodological considerations. PLoS One (2017) 12(2):e0167969. doi:10.1371/journal.pone.0167969

16. Kosaka N, Iguchi H, Ochiya T. Circulating microRNA in body fluid: a new potential biomarker for cancer diagnosis and prognosis. Cancer Sci (2010) 101:2087-92. doi:10.1111/j.1349-7006.2010.01650.x

17. Pritchard CC, Cheng HH, Tewari M. MicroRNA profiling: approaches and considerations. Nat Rev Genet (2012) 13:358-69. doi:10.1038/nrg3198

18. Calin GA, Dumitru CD, Shimizu M, Bichi R, Zupo S, Noch E, et al. Frequent deletions and down-regulation of micro-RNA genes miR15 and miR16 at 13 q14 in chronic lymphocytic leukemia. Proc Natl Acad Sci U S A (2002) 99:15524-9. doi:10.1073/pnas.242606799

19. Correia CN, Nalpas NC, McLoughlin KE, Browne JA, Gordon SV, MacHugh DE, et al. Circulating microRNAs as potential biomarkers of infectious disease. Front Immunol (2017) 8:118. doi:10.3389/fimmu.2017.00118

20. Witwer KW. Circulating microRNA biomarker studies: pitfalls and potential solutions. Clin Chem (2015) 61:56-63. doi:10.1373/clinchem.2014.221341

21. Iftikhar H, Carney GE. Evidence and potential in vivo functions for biofluid miRNAs: from expression profiling to functional testing: potential roles of extracellular miRNAs as indicators of physiological change and as agents of intercellular information exchange. Bioessays (2016) 38:367-78. doi:10.1002/ bies. 201500130

22. Arroyo JD, Chevillet JR, Kroh EM, Ruf IK, Pritchard CC, Gibson DF, et al. Argonaute 2 complexes carry a population of circulating microRNAs independent of vesicles in human plasma. Proc Natl Acad Sci U S A (2011) 108:5003-8. doi:10.1073/pnas.1019055108

23. Turchinovich A, Weiz L, Langheinz A, Burwinkel B. Characterization of extracellular circulating microRNA. Nucleic Acids Res (2011) 39:7223-33. doi:10.1093/nar/gkr254

24. Gümürdü A, Yildiz R, Eren E, Karakülah G, Ünver T, Genç Ş, et al. MicroRNA exocytosis by large dense-core vesicle fusion. Sci Rep (2017) 7:45661. doi:10.1038/srep45661

25. Ha M, Kim VN. Regulation of microRNA biogenesis. Nat Rev Mol Cell Biol (2014) 15:509-24. doi:10.1038/nrm3838

26. Jonas S, Izaurralde E. Towards a molecular understanding of microRNAmediated gene silencing. Nat Rev Genet (2015) 16:421-33. doi:10.1038/nrg3965

27. Makarova JA, Shkurnikov MU, Wicklein D, Lange T, Samatov TR, Turchinovich AA, et al. Intracellular and extracellular microRNA: an update on localization and biological role. Prog Histochem Cytochem (2016) 51:33-49. doi:10.1016/j.proghi.2016.06.001

28. Lee Y, Kim M, Han J, Yeom KH, Lee S, Baek SH, et al. MicroRNA genes are transcribed by RNA polymerase II. EMBO J (2004) 23:4051-60. doi:10.1038/ sj.emboj.7600385

29. Lee Y, Ahn C, Han J, Choi H, Kim J, Yim J, et al. The nuclear RNase III Drosha initiates microRNA processing. Nature (2003) 425:415-9. doi:10.1038/ nature01957

30. Zhang H, Kolb FA, Brondani V, Billy E, Filipowicz W. Human Dicer preferentially cleaves dsRNAs at their termini without a requirement for ATP. EMBO $J$ (2002) 21:5875-85. doi:10.1093/emboj/cdf582

31. Chendrimada TP, Gregory RI, Kumaraswamy E, Norman J, Cooch N, Nishikura K, et al. TRBP recruits the Dicer complex to Ago2 for microRNA processing and gene silencing. Nature (2005) 436:740-4. doi:10.1038/ nature 03868

32. Meister G, Landthaler M, Patkaniowska A, Dorsett Y, Teng G, Tuschl T. Human Argonaute 2 mediates RNA cleavage targeted by miRNAs and siRNAs. Mol Cell (2004) 15:185-97. doi:10.1016/j.molcel.2004.07.007

33. Okamura K, Ishizuka A, Siomi H, Siomi MC. Distinct roles for argonaute proteins in small RNA-directed RNA cleavage pathways. Genes Dev (2004) 18:1655-66. doi:10.1101/gad.1210204

34. Iwasaki S, Kobayashi M, Yoda M, Sakaguchi Y, Katsuma S, Suzuki T, et al. Hsc70/ Hsp90 chaperone machinery mediates ATP-dependent RISC loading of small RNA duplexes. Mol Cell (2010) 39:292-9. doi:10.1016/j.molcel.2010.05.015

35. Bartel DP. MicroRNAs: target recognition and regulatory functions. Cell (2009) 136:215-33. doi:10.1016/j.cell.2009.01.002

36. Liu J, Carmell MA, Rivas FV, Marsden CG, Thomson JM, Song JJ, et al. Argonaute 2 is the catalytic engine of mammalian RNAi. Science (2004) 305:1437-41. doi:10.1126/science.1102513

37. Kosaka N, Iguchi H, Yoshioka Y, Takeshita F, Matsuki Y, Ochiya T, et al. Secretory mechanisms and intercellular transfer of microRNAs in living cells. J Biol Chem (2010) 285:17442-52. doi:10.1074/jbc.M110.107821

38. Trajkovic K, Hsu C, Chiantia S, Rajendran L, Wenzel D, Wieland F, et al. Ceramide triggers budding of exosome vesicles into multivesicular endosomes. Science (2008) 319:1244-7. doi:10.1126/science.1153124

39. Ostrowski M, Carmo NB, Krumeich S, Fanget I, Raposo G, Savina A, et al. Rab27a and Rab27b control different steps of the exosome secretion pathway. Nat Cell Biol (2010) 12:19-30; sup pp 11-3. doi:10.1038/ncb2000

40. Colombo M, Raposo G, Thery C. Biogenesis, secretion, and intercellular interactions of exosomes and other extracellular vesicles. Annu Rev Cell Dev Biol (2014) 30:255-89. doi:10.1146/annurev-cellbio-101512-122326

41. Vlassov AV, Magdaleno S, Setterquist R, Conrad R. Exosomes: current knowledge of their composition, biological functions, and diagnostic and therapeutic potentials. Biochim Biophys Acta (2012) 1820:940-8. doi:10.1016/j. bbagen.2012.03.017

42. Raposo G, Stoorvogel W. Extracellular vesicles: exosomes, microvesicles, and friends. J Cell Biol (2013) 200:373-83. doi:10.1083/jcb.201211138

43. Johnstone RM, Adam M, Hammond JR, Orr L, Turbide C. Vesicle formation during reticulocyte maturation. Association of plasma membrane activities with released vesicles (exosomes). J Biol Chem (1987) 262:9412-20.

44. Chevillet JR, Kang Q, Ruf IK, Briggs HA, Vojtech LN, Hughes SM, et al. Quantitative and stoichiometric analysis of the microRNA content of exosomes. Proc Natl Acad Sci U S A (2014) 111:14888-93. doi:10.1073/pnas. 1408301111

45. Laurent LC, Abdel-Mageed AB, Adelson PD, Arango J, Balaj L, Breakefield X, et al. Meeting report: discussions and preliminary findings on extracellular RNA measurement methods from laboratories in the NIH extracellular RNA communication consortium. J Extracell Vesicles (2015) 4:26533. doi:10.3402/ jev.v4.26533

46. Alexander M, Hu R, Runtsch MC, Kagele DA, Mosbruger TL, Tolmachova T, et al. Exosome-delivered microRNAs modulate the inflammatory response to endotoxin. Nat Commun (2015) 6:7321. doi:10.1038/ncomms8321

47. Guzman N, Agarwal K, Asthagiri D, Yu L, Saji M, Ringel MD, et al. Breast cancer-specific miR signature unique to extracellular vesicles includes "microRNA-like" tRNA fragments. Mol Cancer Res (2015) 13:891-901. doi:10.1158/1541-7786.MCR-14-0533

48. Gibbings DJ, Ciaudo C, Erhardt M, Voinnet O. Multivesicular bodies associate with components of miRNA effector complexes and modulate miRNA activity. Nat Cell Biol (2009) 11:1143-9. doi:10.1038/ncb1929

49. Skog J, Würdinger T, van Rijn S, Meijer DH, Gainche L, Sena-Esteves M, et al. Glioblastoma microvesicles transport RNA and proteins that promote tumour growth and provide diagnostic biomarkers. Nat Cell Biol (2008) 10:1470-6. doi:10.1038/ncb1800

50. van Balkom BW, Eisele AS, Pegtel DM, Bervoets S, Verhaar MC. Quantitative and qualitative analysis of small RNAs in human endothelial cells and exosomes provides insights into localized RNA processing, degradation and sorting. J Extracell Vesicles (2015) 4:26760. doi:10.3402/jev.v4.26760

51. Stevanato L, Thanabalasundaram L, Vysokov N, Sinden JD. Investigation of content, stoichiometry and transfer of miRNA from human neural stem cell line derived exosomes. PLoS One (2016) 11:e0146353. doi:10.1371/journal. pone. 0146353 
52. Paggetti J, Haderk F, Seiffert M, Janji B, Distler U, Ammerlaan W, et al. Exosomes released by chronic lymphocytic leukemia cells induce the transition of stromal cells into cancer-associated fibroblasts. Blood (2015) 126:1106-17. doi:10.1182/blood-2014-12-618025

53. Cocucci E, Racchetti G, Meldolesi J. Shedding microvesicles: artefacts no more. Trends Cell Biol (2009) 19:43-51. doi:10.1016/j.tcb.2008.11.003

54. Kowal J, Tkach M, Thery C. Biogenesis and secretion of exosomes. Curr Opin Cell Biol (2014) 29:116-25. doi:10.1016/j.ceb.2014.05.004

55. Simpson RJ, Kalra H, Mathivanan S. ExoCarta as a resource for exosomal research. J Extracell Vesicles (2012) 1:18374. doi:10.3402/jev.v1i0.18374

56. Han W, Rhee JS, Maximov A, Lin W, Hammer RE, Rosenmund C, et al. C-terminal ECFP fusion impairs synaptotagmin 1 function: crowding out synaptotagmin 1. J Biol Chem (2005) 280:5089-100. doi:10.1074/jbc. M408757200

57. Hunter MP, Ismail N, Zhang X, Aguda BD, Lee EJ, Yu L, et al. Detection of microRNA expression in human peripheral blood microvesicles. PLoS One (2008) 3:e3694. doi:10.1371/journal.pone.0003694

58. Akers JC, Gonda D, Kim R, Carter BS, Chen CC. Biogenesis of extracellular vesicles (EV): exosomes, microvesicles, retrovirus-like vesicles, and apoptotic bodies. J Neurooncol (2013) 113:1-11. doi:10.1007/s11060-0131084-8

59. Kowal J, Arras G, Colombo M, Jouve M, Morath JP, Primdal-Bengtson B, et al. Proteomic comparison defines novel markers to characterize heterogeneous populations of extracellular vesicle subtypes. Proc Natl Acad Sci U S A (2016) 113:E968-77. doi:10.1073/pnas.1521230113

60. Zernecke A, Bidzhekov K, Noels H, Shagdarsuren E, Gan L, Denecke B, et al. Delivery of microRNA-126 by apoptotic bodies induces CXCL12dependent vascular protection. Sci Signal (2009) 2:ra81. doi:10.1126/scisignal. 2000610

61. Wang K, Zhang S, Weber J, Baxter D, Galas DJ. Export of microRNAs and microRNA-protective protein by mammalian cells. Nucleic Acids Res (2010) 38:7248-59. doi:10.1093/nar/gkq601

62. Vickers KC, Palmisano BT, Shoucri BM, Shamburek RD, Remaley AT. MicroRNAs are transported in plasma and delivered to recipient cells by high-density lipoproteins. Nat Cell Biol (2011) 13:423-33. doi:10.1038/ ncb2210

63. Tabet F, Vickers KC, Cuesta Torres LF, Wiese CB, Shoucri BM, Lambert G, et al. HDL-transferred microRNA-223 regulates ICAM-1 expression in endothelial cells. Nat Commun (2014) 5:3292. doi:10.1038/ncomms 4292

64. Sheinerman KS, Umansky SR. Circulating cell-free microRNA as biomarkers for screening, diagnosis and monitoring of neurodegenerative diseases and other neurologic pathologies. Front Cell Neurosci (2013) 7:150. doi:10.3389/ fncel.2013.00150

65. Winkler $\mathrm{H}$. The adrenal chromaffin granule: a model for large dense core vesicles of endocrine and nervous tissue. J Anat (1993) 183(Pt 2):237-52.

66. Jahn R, Scheller RH. SNAREs - engines for membrane fusion. Nat Rev Mol Cell Biol (2006) 7:631-43. doi:10.1038/nrm2002

67. Zhu JJ, Liu YF, Zhang YP, Zhao CR, Yao WJ, Li YS, et al. VAMP3 and SNAP23 mediate the disturbed flow-induced endothelial microRNA secretion and smooth muscle hyperplasia. Proc Natl Acad Sci U S A (2017) 114(31):8271-6. doi:10.1073/pnas.1700561114

68. Geppert M, Ullrich B, Green DG, Takei K, Daniels L, De Camilli P, et al. Synaptic targeting domains of synapsin I revealed by transgenic expression in photoreceptor cells. EMBO J (1994) 13:3720-7.

69. Park Y, Hernandez JM, van den Bogaart G, Ahmed S, Holt M, Riedel D, et al. Controlling synaptotagmin activity by electrostatic screening. Nat Struct Mol Biol (2012) 19:991-7. doi:10.1038/nsmb.2375

70. Poy MN, Eliasson L, Krutzfeldt J, Kuwajima S, Ma X, Macdonald PE, et al. A pancreatic islet-specific microRNA regulates insulin secretion. Nature (2004) 432:226-30. doi:10.1038/nature03076

71. Poy MN, Hausser J, Trajkovski M, Braun M, Collins S, Rorsman P, et al. miR375 maintains normal pancreatic alpha- and beta-cell mass. Proc Natl Acad Sci U S A (2009) 106:5813-8. doi:10.1073/pnas.0810550106

72. Zhang N, Lin JK, Chen J, Liu XF, Liu JL, Luo HS, et al. MicroRNA 375 mediates the signaling pathway of corticotropin-releasing factor (CRF) regulating pro-opiomelanocortin (POMC) expression by targeting mitogenactivated protein kinase 8. J Biol Chem (2013) 288:10361-73. doi:10.1074/jbc. M112.425504
73. Gai Y, Zhang J, Wei C, Cao W, Cui Y, Cui S. miR-375 negatively regulates the synthesis and secretion of catecholamines by targeting Sp1 in rat adrenal medulla. Am J Physiol Cell Physiol (2017) 312:C663-72. doi:10.1152/ ajpcell.00345.2016

74. Kloosterman WP, Lagendijk AK, Ketting RF, Moulton JD, Plasterk RH. Targeted inhibition of miRNA maturation with morpholinos reveals a role for miR-375 in pancreatic islet development. PLoS Biol (2007) 5:e203. doi:10.1371/journal.pbio.0050203

75. El Ouaamari A, Baroukh N, Martens GA, Lebrun P, Pipeleers D, van Obberghen E. miR-375 targets 3'-phosphoinositide-dependent protein kinase-1 and regulates glucose-induced biological responses in pancreatic beta-cells. Diabetes (2008) 57:2708-17. doi:10.2337/db07-1614

76. Erener S, Mojibian M, Fox JK, Denroche HC, Kieffer TJ. Circulating miR-375 as a biomarker of beta-cell death and diabetes in mice. Endocrinology (2013) 154:603-8. doi:10.1210/en.2012-1744

77. Yin J, Hou P, Wu Z, Wang T, Nie Y. Circulating miR-375 and miR-199a-3p as potential biomarkers for the diagnosis of hepatocellular carcinoma. Tumour Biol (2015) 36:4501-7. doi:10.1007/s13277-015-3092-0

78. Denk J, Boelmans K, Siegismund C, Lassner D, Arlt S, Jahn H, et al. MicroRNA profiling of CSF reveals potential biomarkers to detect Alzheimer's disease. PLoS One (2015) 10:e0126423. doi:10.1371/journal.pone. 0126423

79. Xu J, Chen Q, Zen K, Zhang C, Zhang Q. Synaptosomes secrete and uptake functionally active microRNAs via exocytosis and endocytosis pathways. J Neurochem (2013) 124:15-25. doi:10.1111/jnc.12057

80. Park CK, Xu ZZ, Berta T, Han Q, Chen G, Liu XJ, et al. Extracellular microRNAs activate nociceptor neurons to elicit pain via TLR7 and TRPA1. Neuron (2014) 82:47-54. doi:10.1016/j.neuron.2014.02.011

81. Bayraktar R, Van Roosbroeck K, Calin GA. Cell-to-cell communication: microRNAs as hormones. Mol Oncol (2017) 11(12):1673-86. doi:10.1002/1878-0261.12144

82. Tkach M, Thery C. Communication by extracellular vesicles: where we are and where we need to go. Cell (2016) 164:1226-32. doi:10.1016/j.cell.2016. 01.043

83. Meckes DG Jr. Exosomal communication goes viral. J Virol (2015) 89:5200-3 doi:10.1128/JVI.02470-14

84. Voinnet O, Vain P, Angell S, Baulcombe DC. Systemic spread of sequencespecific transgene RNA degradation in plants is initiated by localized introduction of ectopic promoterless DNA. Cell (1998) 95:177-87. doi:10.1016/ S0092-8674(00)81749-3

85. Himber C, Dunoyer P, Moissiard G, Ritzenthaler C, Voinnet O. Transitivitydependent and -independent cell-to-cell movement of RNA silencing. EMBO $J$ (2003) 22:4523-33. doi:10.1093/emboj/cdg431

86. McEwan DL, Weisman AS, Hunter CP. Uptake of extracellular double-stranded RNA by SID-2. Mol Cell (2012) 47:746-54. doi:10.1016/j.molcel.2012. 07.014

87. Winston WM, Sutherlin M, Wright AJ, Feinberg EH, Hunter CP. Caenorhabditis elegans SID-2 is required for environmental RNA interference. Proc Natl Acad Sci U S A (2007) 104:10565-70. doi:10.1073/pnas.0611282104

88. Elhassan MO, Christie J, Duxbury MS. Homo sapiens systemic RNA interference-defective-1 transmembrane family member 1 (SIDT1) protein mediates contact-dependent small RNA transfer and microRNA-21-driven chemoresistance. J Biol Chem (2012) 287:5267-77. doi:10.1074/jbc.M111. 318865

89. Wagner J, Riwanto M, Besler C, Knau A, Fichtlscherer S, Röxe T, et al. Characterization of levels and cellular transfer of circulating lipoproteinbound microRNAs. Arterioscler Thromb Vasc Biol (2013) 33:1392-400. doi:10.1161/ATVBAHA.112.300741

90. Katakowski M, Buller B, Wang X, Rogers T, Chopp M. Functional microRNA is transferred between glioma cells. Cancer Res (2010) 70:8259-63. doi:10.1158/0008-5472.CAN-10-0604

91. Aucher A, Rudnicka D, Davis DM. MicroRNAs transfer from human macrophages to hepato-carcinoma cells and inhibit proliferation. J Immunol (2013) 191:6250-60. doi:10.4049/jimmunol.1301728

92. Fabbri M, Paone A, Calore F, Galli R, Gaudio E, Santhanam R, et al. MicroRNAs bind to toll-like receptors to induce prometastatic inflammatory response. Proc Natl Acad Sci U S A (2012) 109:E2110-6. doi:10.1073/pnas. 1209414109 
93. Lehmann SM, Krüger C, Park B, Derkow K, Rosenberger K, Baumgart J, et al. An unconventional role for miRNA: let-7 activates toll-like receptor 7 and causes neurodegeneration. Nat Neurosci (2012) 15:827-35. doi:10.1038/ nn. 3113

94. Janas T, Janas MM, Sapon K, Janas T. Mechanisms of RNA loading into exosomes. FEBS Lett (2015) 589:1391-8. doi:10.1016/j.febslet.2015.04.036

95. Mittelbrunn M, Gutiérrez-Vázquez C, Villarroya-Beltri C, González S, Sánchez-Cabo F, González MÁ, et al. Unidirectional transfer of microRNA-loaded exosomes from T cells to antigen-presenting cells. Nat Commun (2011) 2:282. doi:10.1038/ncomms1285

96. Villarroya-BeltriC,Gutiérrez-VázquezC,Sánchez-CaboF,Pérez-HernándezD, Vázquez J, Martin-Cofreces N, et al. Sumoylated hnRNPA2B1 controls the sorting of miRNAs into exosomes through binding to specific motifs. Nat Commun (2013) 4:2980. doi:10.1038/ncomms3980
97. Kim T, Gondre-Lewis MC, Arnaoutova I, Loh YP. Dense-core secretory granule biogenesis. Physiology (Bethesda) (2006) 21:124-33. doi:10.1152/physiol.00043. 2005

Conflict of Interest Statement: The author declares that the research was conducted in the absence of any commercial or financial relationships that could be construed as a potential conflict of interest.

Copyright (๑) 2017 Park. This is an open-access article distributed under the terms of the Creative Commons Attribution License (CC BY). The use, distribution or reproduction in other forums is permitted, provided the original author(s) or licensor are credited and that the original publication in this journal is cited, in accordance with accepted academic practice. No use, distribution or reproduction is permitted which does not comply with these terms. 